\title{
Padrão de Fermentação e Composição Químico-Bromatológica de Silagens de Jitirana Lisa (Ipomoea glabra Choisy) e Jitirana Peluda (Jacquemontia asarifolia L. B. Smith) Frescas e Emurchecidas
}

\section{Adriana Guim¹, Edgard Cavalcanti Pimenta Filho², Manoel Francisco de Sousa³, Márcia Maria Cândido Silva ${ }^{4}$}

\begin{abstract}
RESUMO - Um experimento foi conduzido com objetivo de avaliar o padrão de fermentação e a composição química de silagens de jitirana lisa (Ipomoea glabra Choisy) e jitirana peluda (Jacquemontia asarifolia L. B. Smith) frescas e emurchecidas. Para avaliação do padrão de fermentação, os silos (PVC) foram abertos aos 3, 7, 14, 21 e 28 dias de fermentação. Os delineamentos foram inteiramente casualizados, sendo que para avaliação do padrão de fermentação utilizaram-se parcelas sub-subdivididas, e análise de regressão para o fator tempo; e para a composição química, esquema fatorial 2 x 2 (espécie X tratamento), com quatro repetições. Nas forrageiras antes da ensilagem, foram determinados os valores de $\mathrm{pH}, \mathrm{N}-\mathrm{NH}_{3}$ (\% do NT), carboidratos solúveis (CHOs) e poder tampão (PT). A cada tempo de abertura dos silos, foram realizadas as mesmas análises, exceto CHOs e PT. Para a composição química, após 28 dias de armazenamento, foram realizadas análises de MS, PB, FDA, FDN, MO, MM, EE e carboidratos solúveis residuais. Para as silagens de jitirana lisa emurchecida, verificou-se decréscimo linear da MS ( $\mathrm{Y}=26,3421-0,0526 \mathrm{X})$ ao longo do armazenamento. Houve efeito linear crescente para os teores de $\mathrm{N}-\mathrm{NH}_{3}$ das silagens de jitirana lisa fresca (Y=3,6360 + 0,0755X) e jitirana peluda fresca (Y=3,6209+0,0687X). As silagens de jitirana peluda fresca apresentaram maior PB que as de jitirana peluda emurchecida, ao passo que as de jitirana lisa fresca tiveram menor valor de FDN que as de jitirana lisa emurchecida. As duas espécies estudadas são forrageiras nativas do semi-árido nordestino bastante promissoras, constituindo-se em alternativas para a conservação de volumosos via fermentação.
\end{abstract}

Palavras-chave: forrageira, nordeste, semi-árido, silagem

\section{Fermentation Pattern and Chemical Composition of Fresh and Wilted Ipomoea glabra Choisy and Jaquemontia asarifolia L.B. Smith Silages}

\begin{abstract}
An experiment was carried out at to evaluate the fermentation pattern and chemical-bromatologycal composition of fresh and wilted Ipomoea glabra Choisy and Jaquemontia asarifolia L.B. Smith silages. To evaluate the fermentation pattern silos were open in 3, 7, 14, 21 e 28 days of fermentation. The used design was completely randomized in split-plot to the fermentation pattern; and factorial outline $2 \mathrm{X} 2$ with four reapplication to the chemical analysis. In the material before ensiling were determined $\mathrm{pH}$ values, $\mathrm{NH}_{3}-\mathrm{N}$ (\% of total nitrogen), soluble carbohydrates (SC) and buffer capacity (BC). At each silo opening, the same analyses were perfomed, except for SC and BC. After 28 days of conservation, contents of dry matter (DM), crude protein (CP), organic matter (OM), mineral matter (MM), acid detergent fiber (ADF), neutral detergent fiber (NDF), ether extract (EE) and soluble carbohydrates residual (SCr) were analyzed. For Ipomoea glabra Choisy wilted silages, the DM content during fermentative process showed linear decrease $(\mathrm{Y}=26.3421-.0526 \mathrm{X})$. It was observed linear increase in $\mathrm{NH}_{3}-\mathrm{N}$ on the Ipomoea glabra Choisy fresh silages $(\mathrm{Y}=3.6360+.755 \mathrm{X})$ and Jaquemontia asarifolia L.B. Smith fresh silages $(\mathrm{Y}=3.6209+.0687 \mathrm{X})$. The results of chemical composition demonstrated Jaquemontia asarifolia L.B. Smith fresh silages presented higher CP than Jaquemontia asarifolia L.B. Smith wilted silages. Ipomoea glabra Choisy fresh silages showed lower NDF values than Ipomoea glabra Choisy wilted silages. Both species studied had showed it self to be native forages of north east region to forage conservation.
\end{abstract}

Key Words: forage, north east region, semi arid, silage

\section{Introdução}

A vegetação nativa do semi-árido do Nordeste brasileiro, conhecida como caatinga, ocupa uma área de, aproximadamente, $850.000 \mathrm{~km}^{2}$, em torno de $10 \%$ da área total do Brasil. Nesta região, as atividades agro-pastoris, nos últimos séculos de exploração, modificaram sensivelmente a composição florística e a capacidade de produção de forragem (Carvalho et al., 1998).

\footnotetext{
${ }^{1}$ Professora da Universidade Federal Rural de Pernambuco - R. Dom Manoel de Medeiros, S/N Recife (PE) CEP: $52171-900$. E.mail: aguim@ufrpe.br

2 Professor da Universidade Federal da Paraíba - CCA/ Campus III Areia (PB) E.mail: edgard@cca.ufpb.br

${ }^{3}$ Mestre em Zootecnista pela UFPB.

${ }^{4}$ Doutoranda em Zootecnia da Universidade Federal da Viçosa (MG).
} 
A vegetação da caatinga tem grande importância para a manutenção da pecuária no Nordeste do Brasil, pois apresenta grande diversidade em sua flora, com inúmeras espécies arbustivas, arbóreas e herbáceas consumidas por bovinos, caprinos e ovinos. As espécies lenhosas, muitas indesejáveis, distribuídas nos sítios ecológicos da região, ocupam cada vez mais espaços, dificultando o acesso dos animais ao estrato herbáceo. Neste, encontram-se espécies como a jitirana lisa e a jitirana peluda, pertencentes à família das convolvuláceas, muito abundante na região nordestina. Estas espécies são consideradas como invasoras de pastagens.

O termo jitirana designa as trepadeiras de gênero Ipomoea, da família das convolvuláceas, dentre as várias espécies desta família, destaca-se a jitirana lisa de nome científico Ipomoea glabra Choisy (Braga, 1976; Correia, 1969). Essas crescem, segundo Braga (1976), em lugares úmidos, brejos, beira de matas, clareiras, roçados. Os seus caules volúveis, fortes e longos, às vezes espinhosos, abraçam a vegetação rasteira, afogando-a em suas hastes, cobrindo-a com suas hastes e flores, dando aspecto aos tabuleiros, carrascos, campos e margens de caatingas. Suas sementes são avidamente procuradas por caprinos e ovinos. Ainda segundo Braga (1976), no Ceará, existem várias espécies do gênero Jacquemontia e família das convolvuláceas com o nome de jitirana miúda, também conhecida por Jitirana peluda (Jacquemontia asarifolia L. B. Smith), que é uma trepadeira herbácea, com flores brancas ou azuis e abundantes durante a época chuvosa nas encostas secas e pedregosas das serras. Suas sementes são muito apreciadas por ovinos e caprinos.

Barbosa (1997) descreveu sucintamente as espécies destacadas dentro do enfoque supracitado: a) Jitirana Lisa - planta anual, trepadeira, herbácea, com grande número de ramificações; caule glabro; folhas alternas, lanceoladas e oblongas, glabras; inflorescência axilar em cimeira com 4-8 flores pediceladas e articuladas. b) Jitirana Peluda - planta herbácea, anual, trepadeira; caule revestido de pubescência hirsuta e amarelada; folhas alternas, membranáceas; inflorescência longamente pedunculada com poucas flores brancas.

As pesquisas com forrageiras nativas do semiárido nordestino devem ser consideradas as características particulares desse sistema de produção e as tecnologias a serem adotadas devem concordar com a realidade local. A manipulação de árvores, arbustos e herbáceas forrageiras, para o aumento da produção de forragens e por extensão da produção animal, requer conhecimento adequado de suas características de produção de fitomassa e do valor nutritivo, além de avaliações dos impactos econômico, ecológico entre outros.

Grande quantidade de espécies herbáceas, originadas da região, pode ser avaliada como forrageiras promissoras. Entretanto, a riqueza florística forrageira da caatinga é pouco conhecida, dificultando a seleção de espécies com potencial para melhoramento de pastagens nativas na região. Segundo Araújo Filho \& Carvalho (1997), essa deficiência no conhecimento contribui para a prevalência de um manejo da vegetação puramente extrativista, carecendo de prática e tecnologia adequadas ao aporte de uma base de sustentabilidade nos ecossistemas da caatinga.

As árvores, os arbustos e as herbáceas têm participação significativa na dieta de ruminantes e representam boa parte na produção de fitomassa, útil aos animais, dos diferentes sítios ecológicos da caatinga, contribuindo decisivamente para a alimentação dos rebanhos ao longo do ano (Vieira et al., 1998).

Existe grande número de publicações que enfatizam a utilização de gramíneas indicadas como as forrageiras mais adequadas para a prática da ensilagem, como é o caso do milho e do sorgo. Em se tratando da utilização de forrageiras da região semi-árida nordestina, estas informações são ainda mais escassas.

Inúmeras espécies forrageiras nativas no nordeste poderão, possivelmente, ser aproveitadas para a prática da ensilagem, mas ainda requerem estudos de avaliação do potencial produtivo e da mão-de-obra necessária para adoção dessa técnica. Desse modo, em uma região castigada pela severa escassez de forragens no período crítico do ano, podem-se observar áreas de forrageiras estabelecidas (nativas) onde o manejo adequado com práticas simples poderia elevar a eficiência na produção animal.

A estacionalidade de produção de forragens na região nordestina tem levado a inadequada nutrição dos rebanhos bovinos, caprinos e ovinos, em determinadas épocas do ano. Entre as possíveis práticas que os pecuaristas poderiam utilizar para melhorar a alimentação e a produção animal nestas épocas, cita-se a ensilagem.

A ensilagem é uma prática relativamente fácil, porém, ao adotar essa prática, é necessário que se tenha informações sobre o seu processo, com o intuito de reduzir perdas, aumentar a produtividade e

R. Bras. Zootec., v.33, n.6, p.2214-2223, 2004 (Supl. 3) 
a qualidade final do produto, principalmente sobre o padrão de fermentação.

Segundo McDonald et al. (1991), os fatores que determinam o padrão de fermentação, durante a ensilagem, são os que interagem entre si: conteúdo de matéria seca, teor de carboidratos solúveis e capacidade tamponante da planta. O valor de $\mathrm{pH}$ e os teores de nitrogênio amoniacal se constituem, também, em características conseqüentes do processo fermentativo da ensilagem.

$\mathrm{O}$ teor de umidade elevado de forragens para a prática da ensilagem interfere de forma negativa no processo fermentativo. $\mathrm{O}$ excesso de umidade impede fermentação desejável no silo, pois o valor de $\mathrm{pH}$ abaixo do qual o crescimento de clostrídeos é inibido varia diretamente com o teor de matéria seca da planta e, a menos que os níveis de carboidratos solúveis sejam excepcionalmente altos, a ensilagem de material úmido poderá sofrer fermentação butírica, resultando em altas perdas e silagem de baixo valor nutritivo (McDonald et al., 1991).

O principal método de reduzir a umidade do material a ser ensilado é o emurchecimento no campo. Essa técnica possibilita o armazenamento de forragens cortadas com baixo teor de matéria seca por um processo simples, em que as fermentações indesejáveis são facilmente controladas pelo aumento da pressão osmótica (Muck, 1990).

A validez da utilização de silagens como uma das alternativas para combater a escassez de forragens nos períodos críticos do semi-árido nordestino sempre é mencionada nos estudos de viabilidade da pecuária local. No entanto, ao ser analisado o índice de adoção dessa prática pelos criadores dessa região, torna-se difícil entender a não adoção dessa técnica em um ambiente onde o armazenamento de forragens é condição essencial à produção animal.

Objetivou-se, com este trabalho, avaliar o padrão de fermentação e a composição químicobromatológica de silagens de jitirana lisa (Ipomoea glabra Choisy) e jitirana peluda (Jacquemontia asarifolia L. B. Smith) frescas e emurchecidas.

\section{Material e Métodos}

Foi conduzido um experimento no Laboratório de Análises de Alimentos e Nutrição Animal do Departamento de Zootecnia do Centro de Ciências Agrárias, Campus III da Universidade Federal da Paraíba, localizado no município de Areia - PB.

R. Bras. Zootec., v.33, n.6, p.2214-2223, 2004 (Supl. 3)
A forragem foi proveniente da Estação Experimental da Universidade Federal da Paraíba, localizada no município de São João do Cariri, microrregião do Cariri oriental paraibano.

As condições climatológicas prevalecentes durante o processo de ensilagem (11/08/2000) foram: temperaturas máxima e mínima de $27,4^{\circ} \mathrm{C}$ e $17,2^{\circ} \mathrm{C}$, respectivamente; 8,4 horas de insolação; velocidade média do vento de $16,47 \mathrm{~m} / \mathrm{s}$ e umidade relativa do ar de $66,50 \%$. A precipitação pluviométrica de junho e julho foi de 37,9 e 58,9 mm e a temperatura média, no mesmo período, de $25,04^{\circ} \mathrm{C}$ e $23,4^{\circ} \mathrm{C}$.

Por ocasião da colheita do material, foram obtidas amostras de solo, que, após análises, revelaram solo classificado como bruno não-cálcico, pouco espesso e pedregoso, com as seguintes características químicas: pH em água (1:2,5) de 6,0; 0,05 eq. Mg/100 mL de Al trocável; 6,6 eq. Mg/100 mL de Ca+Mg; 6,1 e 30 ppm de $\mathrm{P}$ e $\mathrm{K}$, respectivamente, com textura média.

As jitiranas lisa e peluda encontravam-se em pleno estádio de florescimento, ambas colhidas de uma área de pastagem nativa de, aproximadamente, 1,0 ha. Após a colheita, o material foi picado em máquina forrageira convencional, obtendo-se partículas de 2,0 a 3,0 cm e dividida em duas porções, sendo metade levada à exposição ao sol por 4 horas e 30 minutos para o emurchecimento e a outra metade, ensilada fresca.

Utilizaram-se silos experimentais confeccionados com tubos "PVC", com $50 \mathrm{~cm}$ de altura e $15 \mathrm{~cm}$ de diâmetro, com capacidade aproximada de $8 \mathrm{~kg}$. Para a compactação, foram usados soquetes de madeira, proporcionando a todos os tratamentos densidade próxima a $500 \mathrm{~kg}$ de forragem $/ \mathrm{m}^{3}$. A vedação dos silos foi realizada utilizando-se sacos plásticos e fita adesiva. Após a vedação, foram registrados os pesos dos silos, conduzidos ao laboratório de nutrição animal do Centro de Ciências Agrárias da UFPB e mantidos em temperatura ambiente até a abertura.

Os silos foram abertos 3, 7, 14, 21 e 28 dias após a ensilagem. A cada tempo de abertura, o material da parte central de cada silo era retirado, homogeneizado e coletada uma amostra, que era levada à estufa de ventilação a $55^{\circ} \mathrm{C}$ por, aproximadamente, 72 horas, para a pré-secagem e futuras análises laboratoriais.

A cada tempo de abertura do material já homogeneizado, era recolhida outra amostra para extração, com prensa hidráulica, do suco da silagem, que era congelado para posterior determinação do nitrogênio amoniacal ( $\left.\mathrm{N}-\mathrm{NH}_{3}\right)$, expresso em relação 
ao nitrogênio total, segundo metodologia descrita por Preston (1986). Antes do extrato da silagem ser congelado, foram determinados os valores absolutos do $\mathrm{pH}$, com uso de potenciômetro. Essas análises foram realizadas também nas forragens no momento da ensilagem.

Após secagem, as amostras foram moídas em moinho estacionário com peneira de crivo de $1 \mathrm{~mm}$ e armazenadas em copos de vidro devidamente identificados e hermeticamente fechados. A determinação da composição bromatológica em matéria seca (MS), nitrogênio total (NT), matéria mineral (MM), fibra em detergente neutro (FDN), fibra em detergente ácido (FDA), extrato etéreo (EE) e matéria orgânica (MO) foi realizada segundo a metodologia descrita por Silva (1981).

Além das análises bromatológicas supracitadas, para as forragens no momento da ensilagem e após 28 dias de armazenamento, foram analisados os conteúdos de carboidratos solúveis residuais (CHOr) e de carboidratos residuais, segundo a metodologia descrita por Johnson et al. (1966). Apenas para as forragens no momento da ensilagem foi realizada a determinação do poder tampão (PT), conforme metodologia de Playne \& McDonald (1966).

As características químicas e bromatológicas da forragem no momento da ensilagem (material fresco) são apresentadas nas Tabelas 1 e 2.

Para avaliar o padrão de fermentação, utilizou-se o delineamento experimental inteiramente casualizado, com fatores submetidos ao esquema de parcelas subsubdivididas, alocando as espécies (jitirana lisa ejitirana peluda) nas parcelas, os tratamentos (fresco e emurchecido) nas subparcelas e os tempos de abertura (3, 7, 14, 21 e 28 dias) nas sub-subparcelas, com quatro repetições, totalizando 80 silos, com desdobramento dos graus de liberdade do fator tempo em regressão polinomial. Para a composição bromatológica, utilizouse esquema fatorial ( 2 x 2), referentes às duas espécies de jitirana (lisa e peluda) e aos dois tratamentos (fresco e emurchecido), com quatro repetições, totalizando 16 silos. As médias foram comparadas entre si, a 5\% de probabilidade, pelo teste Tukey. Em ambos os delineamentos, a análise dos dados foi realizada por intermédio do Programa de Análises Estatísticas -SAEG (UFV, 1997).

Tabela 1 - Valores médios do poder tampão $(\mathrm{PT}), \mathrm{pH}$, carboidratos solúveis $(\mathrm{CHOs})$ e nitrogênio amoniacal $\left(\mathrm{N}-\mathrm{NH}_{3}\right)$ das forragens no momento da ensilagem

Table 1 - Values means of buffer cappacity (BC), $\mathrm{pH}$ soluble carbohydrates (SC) and amonical nitrogen $\left(\mathrm{NH}_{3}-\mathrm{N}\right)$ of forages at ensiling time

\begin{tabular}{|c|c|c|c|c|}
\hline $\begin{array}{l}\text { Forragem } \\
\text { Forage }\end{array}$ & $\begin{array}{l}\text { PT(eq. mg de } \mathrm{HCl} / 100 \mathrm{~g} \mathrm{MS}) \\
B C(\text { eq.mg of } \mathrm{HCl} / 100 \mathrm{~g} \mathrm{DM})\end{array}$ & $\mathrm{pH}$ & $\begin{array}{l}\text { CHOs(\% MS) } \\
\text { SC (\% DM) }\end{array}$ & $\begin{array}{l}\mathrm{N}-\mathrm{NH}_{3}(\% \mathrm{NT}) \\
\mathrm{NH}_{3}-\mathrm{N}(\% \mathrm{TN})\end{array}$ \\
\hline $\begin{array}{l}\text { Jitirana lisa } \\
\text { Ipomoea glabra }\end{array}$ & 26,90 & 5,41 & 10,55 & 0,80 \\
\hline $\begin{array}{l}\text { Jitirana peluda } \\
\text { Jacquemontia asarifolia }\end{array}$ & 32,30 & 5,41 & 9,55 & 1,00 \\
\hline
\end{tabular}

Tabela 2 - Valores médios das porcentagens de matéria seca (MS), proteína bruta (PB), matéria orgânica (MO), matéria mineral (MM), extrato etéreo (EE), fibra em detergente neutro (FDN) e fibra em detergente ácido (FDA) das forragens no momento da ensilagem

Table 2 - Values means of dry matter (DM), crude protein (CP), organic matter (OM), mineral matter (MM), ether extract (EE), neutral detergent fiber (NDF) and acid detergent fiber (ADF) contents of forages at ensiling time

\begin{tabular}{|c|c|c|c|c|c|c|c|}
\hline $\begin{array}{l}\text { Forragem } \\
\text { Forage }\end{array}$ & $\begin{array}{l}\text { MS } \\
D M\end{array}$ & $\begin{array}{l}\mathrm{PB}^{1} \\
C P^{1}\end{array}$ & $\begin{array}{l}\mathrm{MO}^{1} \\
O M^{1}\end{array}$ & $\begin{array}{l}\mathrm{MM}^{1} \\
M M^{1}\end{array}$ & $\begin{array}{l}E E^{1} \\
E E^{1}\end{array}$ & $\begin{array}{l}\mathrm{FDN}^{1} \\
N \mathrm{DF}^{1}\end{array}$ & $\begin{array}{l}\mathrm{FDA}^{1} \\
A D F^{1}\end{array}$ \\
\hline $\begin{array}{l}\text { Jitirana lisa } \\
\text { Ipomoea glabra }\end{array}$ & 17,55 & 17,06 & 91,55 & 8,45 & 4,20 & 46,57 & 33,77 \\
\hline $\begin{array}{l}\text { Jitirana peluda } \\
\text { Jacquemontia asarifolia }\end{array}$ & 16,72 & 18,11 & 89,37 & 10,63 & 3,65 & 48,75 & 33,71 \\
\hline
\end{tabular}

${ }^{1}$ Dados com base na matéria seca (dry matter basis).

R. Bras. Zootec., v.33, n.6, p.2214-2223, 2004 (Supl. 3) 


\section{Resultados e Discussão}

A análise de regressão não apresentou significância $(\mathrm{P}>0,05)$ para os teores de matéria seca em função do tempo de fermentação para as silagens de jitirana lisa fresca, jitirana peluda fresca e jitirana peluda emurchecida, sendo os valores estimados provenientes das médias observadas durante o processo fermentativo (Tabela 3), indicando que o tempo de fermentação não influenciou $(\mathrm{P}>0,05)$ os teores médios de matéria seca dessas silagens, que permaneceram constantes até o 28음 dia de armazenamento. Por outro lado, para o conteúdo de matéria seca das silagens de jitirana lisa emurchecida, o modelo de regressão estimado mostrou que houve decréscimo de $0,0525 \%$ no teor de MS para cada unidade de tempo (dia). A análise de regressão, embora tenha estimado efeito linear decrescente $(\mathrm{P}<0,05)$, apresentou baixo coeficiente de correlação (Tabela 3); assim, a curva estimada pode não representar bem a perda de matéria seca durante o processo, ficando muito distante dos pontos realmente observados. Silva et al. (2004), avaliando padrão de fermentação de silagens elaboradas com espécies forrageiras de estrato herbáceo da caatinga nordestina, fresca e emurchecida, observaram que o comportamento da matéria seca, demonstrado pela curva para o material fresco, atingiu o valor máximo por volta do 15ํㅡㄹ dia de fermentação, estimando-se teor de 25,9\% de MS $\left(r^{2}=0,52\right)$. Por outro lado, para o mesmo material, porém emurchecido, os autores não encontraram

Tabela 3 - Médias e equação de regressão dos teores de matéria seca, em função do tempo de fermentação (dias) de silagens de jitirana lisa e peluda, submetidas ou não ao emurchecimento

Table 3 - Averages and regression equation of dry matter trough fermentation time (days) of Ipomoea glabra and Jacquemontia asarifolia submitted or not to wilt

\begin{tabular}{lcc}
\hline $\begin{array}{l}\text { Silagens } \\
\text { Silages }\end{array}$ & $\begin{array}{l}\text { Equação } \\
\text { Equation }\end{array}$ & $\mathrm{r}^{2}$ \\
\hline $\begin{array}{l}\text { Jitirana lisa fresca } \\
\begin{array}{l}\text { Fresh Ipomoea glabra } \\
\text { Jitirana lisa emurchecida }\end{array}\end{array}$ & $\hat{\mathrm{Y}}=17,35$ & - \\
$\begin{array}{l}\text { Wilted Ipomoea glabra } \\
\text { Jitirana peluda fresca }\end{array}$ & $\hat{\mathrm{Y}}=17,50$ & - \\
$\begin{array}{l}\text { Fresh Jacquemontia asarifolia } \\
\text { Jitirana peluda emurchecida } \\
\text { Wilted Jacquemontia asarifolia }\end{array}$ & $\hat{\mathrm{Y}}=24,17$ & - \\
\hline
\end{tabular}

oscilação significativa nos teores de matéria seca ( $\hat{Y}=25,79 \%$ ) ao longo do tempo de fermentação.

Ao se analisar os teores de MS das forragens no momento da ensilagem (Tabela 2), verifica-se que a jitirana lisa possuía maior conteúdo de MS (17,55\%) que a jitirana peluda $(16,72 \%)$. O tempo de emurchecimento por quatro horas e trinta minutos das forragens não foi suficiente para elevar os teores de MS até níveis considerados ótimos para boa fermentação, situados entre 30 e 40\% (Tosi, 1973; Silveira, 1975; Vilela, 1984), embora silagens de híbridos de sorgo com teores de MS entre 25 e 29\% tenham sido consideradas de boa qualidade por Silveira (1988). Porém, cabe ressaltar que as silagens de jitirana lisa emurchecida apresentaram, aproximadamente, $34 \%$ a mais de MS que as silagens de jitirana lisa fresca e para as silagens de jitirana peluda emurchecida esse acréscimo de MS foi somente de 27,5\%.

Nas Figuras 3 e 4, encontram-se os valores médios de $\mathrm{pH}$ das silagens de jitirana lisa e peluda, sob os tratamentos fresco e emurchecido, em função do tempo de armazenamento. Para todas as silagens avaliadas, verificou-se oscilação dos valores de $\mathrm{pH}$ ao longo da fermentação, com queda nas primeiras duas semanas de fermentação e ligeiro aumento do $\mathrm{pH}$ nas duas semanas seguintes.

Rápido declínio do pH é importante para obtenção de silagens de qualidade satisfatória. Nas silagens com menos de $50 \%$ de MS, o pH, normalmente, cai dentro de cinco dias de fermentação (Muck, 1988). Em silagens trabalhadas por Meeske et al. (1993), o

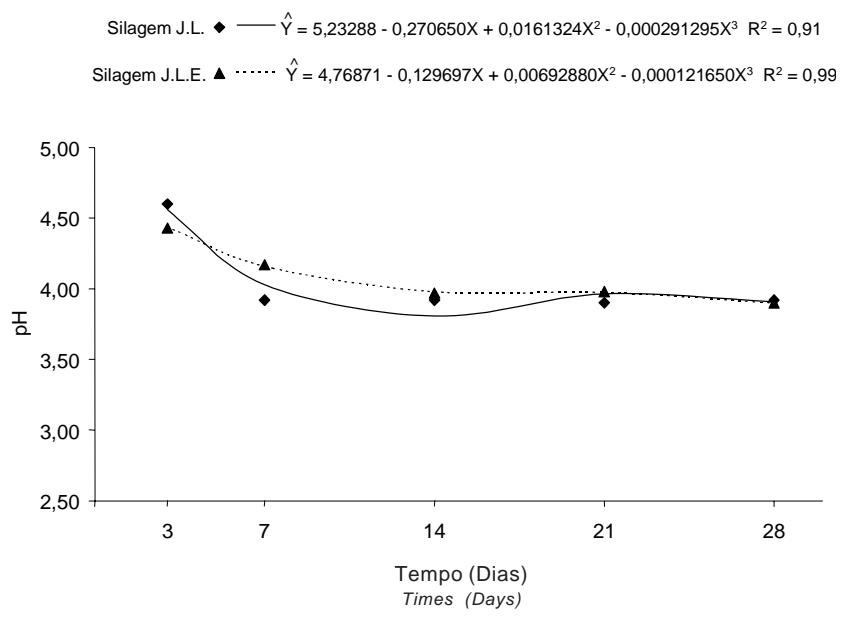

Figura 1 - Valores médios de pH em função do tempo de armazenamento (dias) de silagens de jitirana lisa fresca (JL) e jitirana lisa emurchecida (JLE).

Figure 1 - $\quad p H$ values means through conservation time (days) of fresh (JL) and wilted (JLE) Ipomoea glabra silages. 


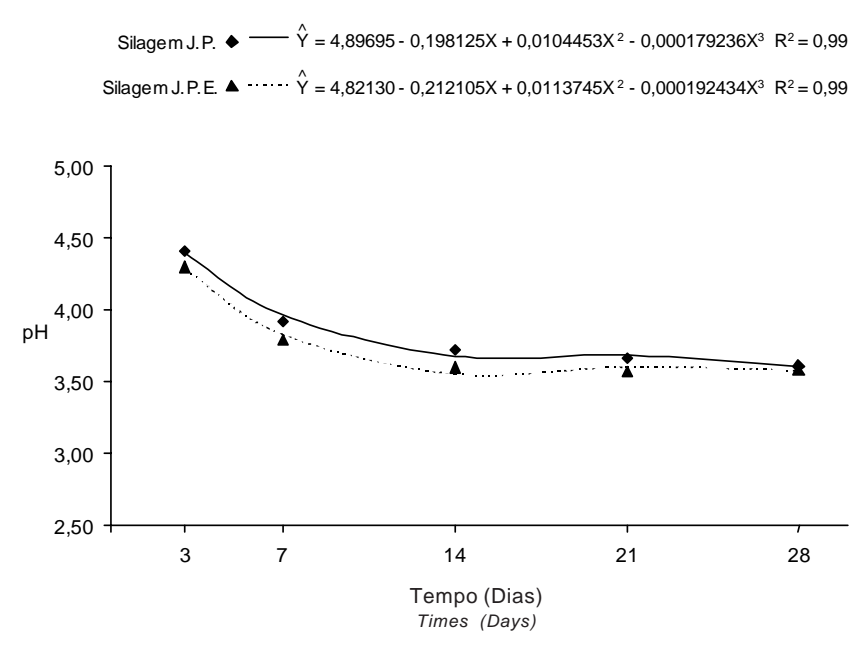

Figura 2 - Valores médios de pH em função do tempo de armazenamento (dias) de silagens de jitirana peluda fresca (JL) e jitirana peluda emurchecida (JLE).

Figure 2 - $p H$ values means through conservation time (days) of fresh (JL) and wilted (JLE) Jacquemontia asarifolia silages.

pH alcançou valores de 4,5, dois dias após a ensilagem e conseguiu a estabilidade com valores em torno de 3,9 no $10^{\mathrm{o}}$ dia de fermentação. Os valores de $\mathrm{pH}$ encontrados no presente trabalho, entre o terceiro e o $28^{\circ}$ dia de ensilagem, oscilaram entre 4,60 e 3,92 (silagem de jitirana lisa fresca); 4,43 e 3,90 (silagem de jitirana lisa emurchecida); 4,41 e 3,61 (silagem de jitirana peluda fresca); e 4,30 e 3,58 (silagem de jitirana peluda emurchecida). A queda do $\mathrm{pH}$ mais pronunciada foi verificada até o sétimo dia de ensilagem em que todas as silagens apresentaram valores abaixo de 4,2, considerado satisfatório para a fermentação. Essa redução acentuada dos valores de $\mathrm{pH}$ poucos dias após a ensilagem é indicativo de que a maioria dos processos fermentativos ocorreu nos primeiros dias de ensilagem.

Ao final de 28 dias de armazenamento, os valores médios de pH foram de 3,92; 3,90; 3,61 e 3,68 para as silagens de jitirana lisa fresca, lisa emurchecida, peluda fresca e peluda emurchecida, respectivamente. Esses resultados sugerem que as quantidades de carboidratos solúveis nas forragens (Tabela 1) foram suficientes para promover a queda do $\mathrm{pH}$ e, conseqüentemente, favorecer a fermentação do material ensilado, uma vez que os teores de MS foram baixos, o que prejudica sobremaneira a fermentação. Lavezzo (1992) comenta que a atividade dos clostrídeos é controlada pelo pH e pela pressão osmótica. Quando esta for reduzida, é necessário pH baixo para inibir aqueles microrganismos e, à medida que a pressão osmótica aumenta, menos ácido será necessário para prevenir suas fermentações indesejáveis. Como a pressão osmótica do interior das células vegetais aumenta com o decréscimo do conteúdo de umidade da planta, entende-se o benefício do emurchecimento. Todavia, se o conteúdo de umidade do material for elevado, é necessário que o nível de carboidratos solúveis seja muito alto para favorecer a atividade das bactérias produtoras de ácido lático e resultar silagem com baixo valor $\mathrm{pH}$. Portanto, quanto mais baixo o $\mathrm{pH}$ em silagens de maior umidade, maior a possibilidade de se ter fermentações de qualidade superior. Nesse sentido, vale salientar que os valores encontrados aos 28 dias de armazenamento para todas as silagens estudadas estavam dentro da faixa aceitável $(3,5$ - 4,2) para obtenção de adequada fermentação, indicando possível redução da atividade de microrganismos responsáveis por fermentações secundárias.

Um fator que ressalta a contribuição dos carboidratos solúveis no processo fermentativo é que mesmo as forragens apresentando poder tampão elevado (Tabela 1) os valores de $\mathrm{pH}$ das respectivas silagens se mantiveram baixos.

Em forragem fresca, em torno de 75 a $90 \%$ do nitrogênio total está presente na proteína, estando o restante na forma de peptídeos, aminoácidos livres, amidas, clorofila e nitratos. A quantidade de $\mathrm{N}-\mathrm{NH}_{3}$ livre corresponde, normalmente, a menos de $1 \%$ do nitrogênio total (McDonald et al., 1991), fato que pode ser verificado no presente trabalho (Tabela 1). Quando a forragem é ensilada, seja fresca ou depois do emurchecimento, a proteólise continua, com conseqüente redução do nitrogênio protéico e aumento do não-protéico (Danley \& Vetter, 1973). Segundo Baron et al. (1986) e Muck (1988), a proteólise em silagens ocorre no primeiro dia de ensilagem, declinando para pequenas taxas após cinco dias de fermentação. Porém, a extensão da proteólise durante a ensilagem é influenciada por vários fatores, incluindo conteúdo de MS, pH e temperatura. Se a queda do $\mathrm{pH}$ for lenta, então mais proteína será quebrada.

Para as silagens de jitirana lisa fresca e emurchecida (Figura 3) e silagem de jitirana peluda fresca (Figura 4), os modelos lineares estimados denotam que com o avançar do tempo de fermentação houve acréscimo na ordem de 0,075; 0,054;

R. Bras. Zootec., v.33, n.6, p.2214-2223, 2004 (Supl. 3) 


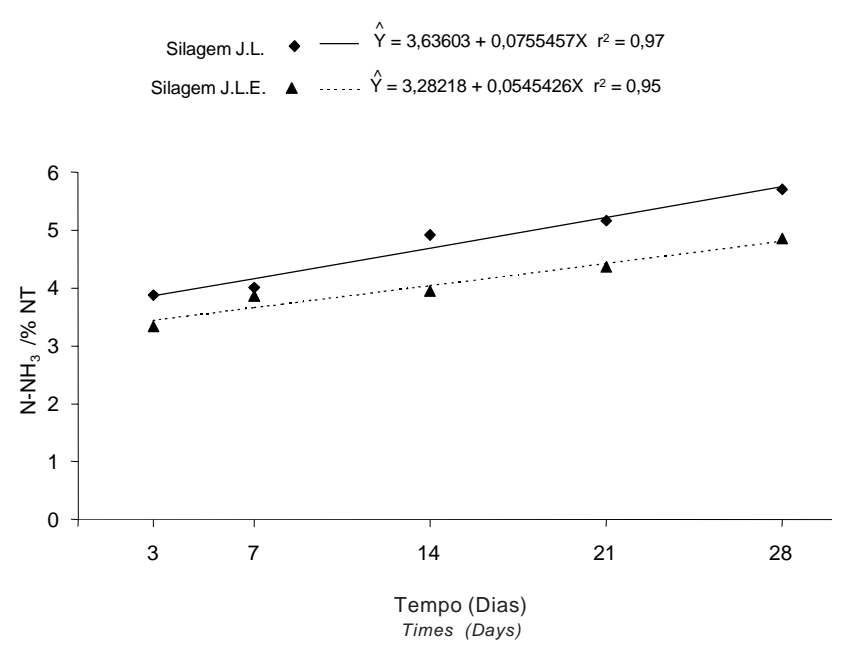

Figura 3 - Teores médios de nitrogênio amoniacal como porcentagem do nitrogênio total $\left(\mathrm{N}-\mathrm{NH}_{3} / \mathrm{NT}\right)$ em função do tempo de fermentação (dias) de silagens de jitirana lisa fresca (J.L.) e emurchecida (J.L.E.).

Figure $3-\mathrm{NH}_{3}-\mathrm{N}$ values means as percentage of total nitrogen through conservation time (days) of fresh (JL) and wilted (JLE) Ipomoea glabra silages.

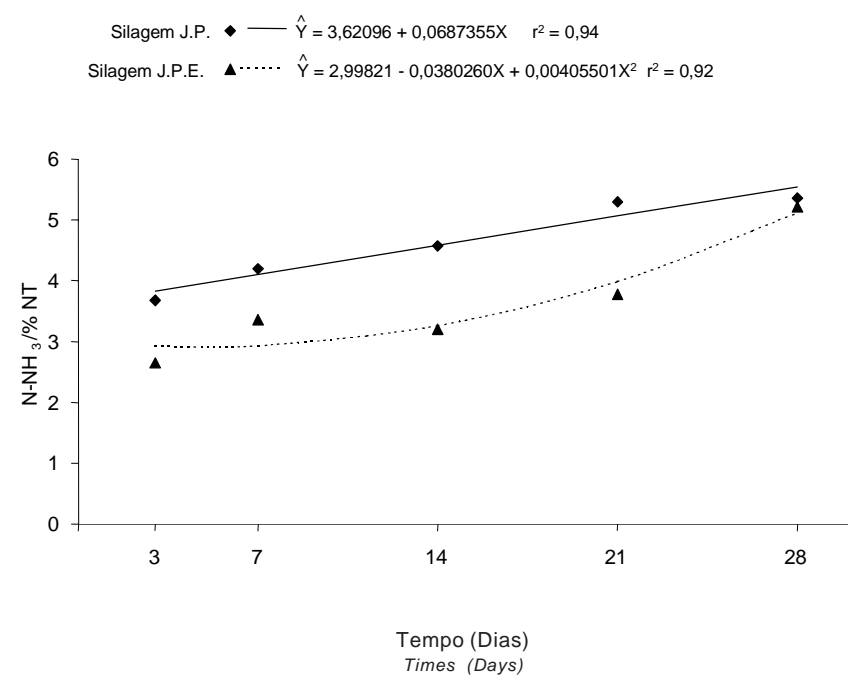

Figura 4 - Teores médios de nitrogênio amoniacal como porcentagem do nitrogênio total $\left(\mathrm{N}-\mathrm{NH}_{3} / \mathrm{NT}\right)$ em função do tempo de fermentação (dias) de silagens de jitirana peluda fresca (J.P.) e emurchecida (J.P.E.).

Figure 4 - $\mathrm{NH}_{3}-\mathrm{N}$ values means as percentage of total nitrogen through conservation time (days) of fresh (JPL) and wilted (JPE) Jacquemontia asarifolia silages.
0,068\% no teor de $\mathrm{N}-\mathrm{NH}_{3}$ para cada unidade de tempo (dia), respectivamente. Para silagem de jitirana peluda emurchecida (Figura 4), foi evidenciado efeito quadrático para esta variável, em que o menor teor de $\mathrm{N}-\mathrm{NH}_{3} / \mathrm{NT}(2,91 \%)$ foi encontrado próximo ao $5^{\circ}$ dia de fermentação.

Embora não tenha ocorrido estabilização dos teores de $\mathrm{N}-\mathrm{NH}_{3} / \mathrm{NT}$ ao longo da fermentação, estes ficaram dentro do limite considerado aceitável, uma vez que nenhuma das silagens apresentou valores superiores a $6 \%$. Tal fato pode ter sido garantido pelos baixos valores de $\mathrm{pH}$, apesar da umidade excessiva do material, uma vez que a maior atividade das proteases ocorre com pH de 5 a 6 (McDonald et al., 1991). É válido ressaltar que as silagens emurchecidas, tanto para a jitirana lisa como para a peluda, apresentaram teores de $\mathrm{N}-\mathrm{NH}_{3}$ inferiores às frescas, confirmando o benefício do aumento da pressão osmótica sobre a possível redução da atividade dos clostrídeos. Para McDonald et al. (1991) e Brito et al. (1998), valores superiores a $10 \%$ são indicativos de proteólise intensa, entretanto Ítavo et al. (1998) considera acentuada quebra da proteína a partir de $8 \%$ de $\mathrm{N}-\mathrm{NH}_{3} / \mathrm{NT}$.

Apesar do comportamento linear crescente demonstrado para o $\mathrm{N}^{-\mathrm{NH}_{3}}$ e os altos teores de MS observados, no momento da abertura dos silos não foram registrados aumento da temperatura e características organolépticas indesejáveis às silagens, indicando que as forragens avaliadas apresentam potencial para serem armazenadas na forma de silagem. Porém, sugere-se que o tempo de emurchecimento seja estendido na tentativa de estabilização da proteólise.

Os resultados referentes aos teores de matéria seca, extrato etéreo, matéria orgânica e matéria mineral das silagens de jitirana lisa e peluda, submetidas ou não ao emurchecimento, após 28 dias de armazenamento encontram-se na Tabela 4. Verifica-se que não houve interação $(\mathrm{P}>0,05)$ entre espécie e tratamento das silagens para as variáveis avaliadas. Porém, houve efeito significativo de espécie sobre o EE das silagens, de modo que aquela confeccionada com jitirana lisa apresentou teor mais elevado $(4,12 \%)$ que aquela confeccionada com jitirana peluda (3,20\%).

Os teores de FDA e de carboidratos solúveis residuais (CHOr) das silagens estudadas não sofreram alterações $(\mathrm{P}>0,05)$ para espécie, tratamento e suas interações (Tabela 5). Segundo Barnett (1967), citado por Danley \& Vetter (1973), durante o processo de fermentação, há grande redução em açúcares

R. Bras. Zootec., v.33, n.6, p.2214-2223, 2004 (Supl. 3) 
Tabela 4 - Teores médios de matéria seca (MS), proteína bruta (PB), matéria orgânica (MO) e matéria mineral (MM) das silagens de jitirana lisa e peluda, submetidas ou não ao emurchecimento, após 28 dias de armazenamento

Table 4 - Dry matter (DM), ether extract (EE), organic matter (OM) and mineral matter (MM) content means of Ipomoea glabra and Jacquemontia asarifolia silages, submited or not to wilt, after 28 days of ensiling

\begin{tabular}{|c|c|c|c|c|}
\hline $\begin{array}{l}\text { Espécie (E) } \\
\text { Specie }(S)\end{array}$ & $\begin{array}{l}\text { MS (\%) } \\
D M(\%)\end{array}$ & $\begin{array}{l}\mathrm{EE}(\%)^{1} \\
\operatorname{EE}(\%)^{1}\end{array}$ & $\begin{array}{l}\mathrm{MO}(\%)^{1} \\
\mathrm{OM}(\%)^{1}\end{array}$ & $\begin{array}{l}\operatorname{MM}(\%)^{1} \\
M M(\%)^{1}\end{array}$ \\
\hline $\begin{array}{l}\text { Silagem Jitirana lisa } \\
\text { Ipomoea glab silages }\end{array}$ & 20,83 & $4,14 \mathrm{a}$ & $89,54 b$ & $10,46 \mathrm{a}$ \\
\hline $\begin{array}{l}\text { Silagem Jitirana peluda } \\
\text { Jacquemontia asarifolia silages } \\
\text { Tratamento }(\mathrm{T}) \\
\text { Treatment }(T)\end{array}$ & 20,68 & $3,20 \mathrm{~b}$ & $91,12 \mathrm{a}$ & $8,88 \mathrm{~b}$ \\
\hline $\begin{array}{l}\text { Silagem fresca } \\
\text { Fresh silage }\end{array}$ & $17,43 b$ & 3,55 & $90,94 \mathrm{a}$ & $9,06 \mathrm{~b}$ \\
\hline $\begin{array}{l}\text { Silagem Emurchecida } \\
\text { Wilted silage } \\
\text { Teste F } \\
\text { F test }\end{array}$ & 24,07 a & 3,78 & 89,72 b & $10,28 \mathrm{a}$ \\
\hline $\begin{array}{l}\mathrm{ES} \\
\mathrm{T} \\
\mathrm{EXT} \\
S \times T\end{array}$ & $\begin{array}{c}0,160 \mathrm{~ns} \\
319,551^{* *} \\
0,002 \mathrm{~ns}\end{array}$ & $\begin{array}{c}10,214 * * \\
0,656 \mathrm{~ns} \\
15,68 \mathrm{~ns}\end{array}$ & $\begin{array}{c}10,192 * * \\
6,096 * \\
0,046 \mathrm{~ns}\end{array}$ & $\begin{array}{c}10,192 * * \\
6,098 * \\
0,046 \mathrm{~ns}\end{array}$ \\
\hline
\end{tabular}

* $5 \%$ de probabilidade; $* * 1 \%$ de probabilidade; ns - não-significativo.

* $5 \%$ of probability; $1 \%$ of probability, ns - not significant.

1 Dados com base na matéria seca (Dry matter basis).

Tabela 5 - Teores médios de fibra em detergente neutro (FDN), fibra em detergente ácido (FDA), proteína bruta (PB) e carboidratos solúveis residuais (CHOr) das silagens de jitirana lisa e peluda, submetidas ou não ao emurchecimento, após 28 dias de armazenamento

Table 5 - Neutral detergent fiber(NDF), acid detergent fiber(ADF), crude protein (CP) and soluble carbohydrates residual (SCr) content means of Ipomoea glabra and Jacquemontia asarifolia silages, submited or not to wilt, after 28 days of ensiling

\begin{tabular}{|c|c|c|c|c|}
\hline & $\begin{array}{l}\text { FDN (\%) } \\
\text { NDF (\%) }\end{array}$ & $\begin{array}{l}\text { FDA }(\%)^{1} \\
\text { ADF }(\%)\end{array}$ & $\begin{array}{l}\mathrm{PB}(\%)^{1} \\
C P(\%)\end{array}$ & $\begin{array}{l}\text { CHOr }(\%)^{1} \\
\text { SCr }(\%)\end{array}$ \\
\hline $\begin{array}{l}\text { Espécie }(\mathrm{E}) \\
\text { Specie }(S)\end{array}$ & & & & \\
\hline $\begin{array}{l}\text { Silagem Jitirana lisa } \\
\text { Ipomoea glab silages }\end{array}$ & 43,95 & 31,93 & 13,89 & 3,08 \\
\hline $\begin{array}{l}\text { Silagem Jitirana peluda } \\
\text { Jacquemontia asarifolia silages } \\
\text { Tratamento }(\mathrm{T}) \\
\text { Treatment }(T)\end{array}$ & 43,52 & 33,51 & 13,49 & 2,94 \\
\hline $\begin{array}{l}\text { Silagem fresca } \\
\text { Fresh silage }\end{array}$ & 42,95 & 32,07 & 14,05 & 2,90 \\
\hline $\begin{array}{l}\text { Silagem emurchecida } \\
\text { Wilted silage } \\
\text { Teste F }\end{array}$ & 44,53 & 33,38 & 13,32 & 3,13 \\
\hline $\begin{array}{l}F \text { Test } \\
\mathrm{E}\end{array}$ & $0,330 \mathrm{~ns}$ & $4,590 \mathrm{~ns}$ & $1,64 \mathrm{~ns}$ & $0,796 \mathrm{~ns}$ \\
\hline $\mathrm{T}$ & 4,545 ns & $3,130 \mathrm{~ns}$ & $5,41 *$ & $2,148 \mathrm{~ns}$ \\
\hline $\begin{array}{l}\text { EXT T } \\
S X T \\
\end{array}$ & $7,537 *$ & 3,320 ns & $22,051 * *$ & $0,244 \mathrm{~ns}$ \\
\hline
\end{tabular}

* $5 \%$ de probabilidade; ${ }^{* *} 1 \%$ de probabilidade; ns - não-significativo.

* $5 \%$ of probability; $1 \%$ of probability, ns - not significant.

${ }^{1}$ Dados com base na matéria seca (Dry matter basis). 
Tabela 6 - Desdobramento da interação espécie $x$ tratamento para proteína bruta (PB) e fibra em detergente neutro (FDN) das silagens de jitirana lisa e peluda, submetidas ou não ao emurchecimento

Table 6 - Interaction between specie and treatment to crude protein (CP) and neutral detergent fiber (NDF) of Ipomoea glabra and Jacquemontia asarifolia silages, submitted or not to wilt

\begin{tabular}{|c|c|c|c|c|}
\hline \multirow{4}{*}{$\begin{array}{l}\text { Espécie } \\
\text { Specie }\end{array}$} & \multicolumn{4}{|c|}{$\begin{array}{c}\text { Tratamento } \\
\text { Treatment }\end{array}$} \\
\hline & \multicolumn{2}{|c|}{$\begin{array}{l}\text { Fresco } \\
\text { Fresh }\end{array}$} & \multicolumn{2}{|c|}{$\begin{array}{l}\text { Emurchecido } \\
\text { Wilted }\end{array}$} \\
\hline & PB (\%) & FDN (\%) & PB (\%) & FDN(\%) \\
\hline & CP (\%) & NDF (\%) & CP (\%) & NDF (\%) \\
\hline $\begin{array}{l}\text { Jitirana lisa } \\
\text { Ipomoea glabr }\end{array}$ & $13,51 \mathrm{aB}$ & $42,14 \mathrm{bA}$ & $14,26 \mathrm{aA}$ & 45,76 aA \\
\hline $\begin{array}{l}\text { Jitirana peluda } \\
\text { Jacquemontia asarifoli }\end{array}$ & $14,58 \mathrm{aA}$ & $43,75 \mathrm{aA}$ & 12,39bB & $43,30 \mathrm{aB}$ \\
\hline
\end{tabular}

Médias nas colunas/linhas com letras maiúsculas/minúsculas distintas, para a mesma variável, diferem pelo teste Tukey (5\%).

Averages within a column/raw with diferent capital letter/small letter, for the same variable, differ by Tukey test (5\%).

solúveis, fato evidenciado nesta pesquisa, porém os teores de CHOr encontrados foram superiores aos citados por McDonald et al. (1991), normalmente abaixo de 2\% da MS. Este resultado pode ser atribuído aos baixos valores de $\mathrm{pH}$ alcançados durante os primeiros dias de fermentação (Figuras 1 e 2).

Houve interação significativa $(\mathrm{P}<0,05)$ entre espécie e tratamento para os teores de FDN e PB, cujo desdobramento encontra-se na Tabela 6. Para as silagens de jitirana lisa, o emurchecimento provocou acréscimo significativo nos teores de FDN (42,14 vs. 45,76\% de FDN, para silagens de material fresco e emurchecido, respectivamente). Porém, nas silagens de jitirana peluda, o emurchecimento não provocou tal efeito (43,75 vs. 43,30\% FDN, na mesma ordem). Por outro lado, ao se verificar o efeito do emurchecimento entre as silagens das duas espécies, nota-se que as de jitirana lisa apresentaram FDN $(45,76 \%)$ superior aos da jitirana peluda $(43,30 \%)$, enquanto para o tratamento fresco, as silagens das duas espécies foram estatisticamente semelhantes (42,14 vs. $43,75 \%$, para as de jitirana lisa e peluda, respectivamente). Para proteína bruta, nota-se que nas silagens de jitirana lisa o emurchecimento não provocou diferenças nos teores de PB em relação às silagens frescas porém, para as silagens de jitirana peluda, o emurchecimento levou a decréscimo da PB em relação às frescas. Considerando-se os tratamentos, quando ensilado fresco, as silagens de jitirana lisa apresentaram menos PB que as de jitirana peluda, porém, sob emurchecimento, o comportamento foi inverso, que pode ser atribuído ao próprio padrão de fermentação.

Mesmo não tendo sido objeto de estudo, o restante das silagens aos 28 dias de fermentação, após as coletas das amostras para sua avaliação, foi oferecido a caprinos para verificar sua aceitação. Os animais estavam confinados, recebendo capim-elefante jovem como volumoso. Vale destacar que foram avidamente consumidas, dando bom indicativo de sua aceitabilidade. Porém, novos estudos deverão ser conduzidos para avaliar o consumo e a digestibilidade das silagens estudadas.

\section{Conclusões}

As silagens estudadas apresentaram padrão de fermentação adequado ao processo, apesar dos baixos teores de matéria seca encontrados, sugerindo novos estudos relativos ao tempo de emurchecimento (présecagem).

Tanto a jitirana lisa como a peluda são forrageiras nativas do semi-árido nordestino muito promissoras, constituindo-se em alternativas para a conservação de volumosos via fermentação. No entanto, é importante deixar clara a necessidade de continuidade e aprofundamento de estudos sobre o assunto.

\section{Literatura Citada}

ARAÚJO FILHO, J.A.; CARVALHO, F.C. Desenvolvimento sustentado da caatinga. Sobral: EMBRAPA-CNPC, 1997.19p. (Circular Técnica, 13) 
BARON, V.S.; STEVENSON, K.R.; BUCHANAN-SMITH, J.G. Proteolysis and fermentation of grain-corn ensiled at several moisture levels and under several simulated storage methods. Canadian Journal of Animal Science, v.66, n.2, p.451-461, 1986.

BARBOSA, H.P. Tabela de composição de alimentos do Estado da Paraíba: Setor agropecuário. João Pessoa: Fundação de Amparo à Pesquisa do Estado da Paraíba, 1997, 165p.

BRAGA, R. Plantas do Nordeste, especialmente do Ceará. 3.ed. Fortaleza: Editora Universitária, 1976. v.42, 540p.

BRITO, A.F.; GONÇALVES, L.C.; RODRIGUES, J.A.S. et al. Qualidade das silagens de sete genótipos de sorgo e seus padrões de fermentação. In: REUNIÃO ANUAL DA SOCIEDADE BRASILEIRA DE ZOOTECNIA, 35., 1998, Botucatu. Anais ... Botucatu: Sociedade Brasileira de Zootecnia, 1998. p.690-692.

CARVALHO, F.C.; ARAÚJO FILHO, J.A.; REGE, M.C. et al. Flutuações dos níveis dos carboidratos de reserva disponíveis nas raízes e no caule do marmeleiro (Croton sonderianus Muell. Arg.). Revista Brasileira de Zootecnia, v.27, n.4, p.670-675, 1998.

CORREIA, M.P. Dicionário das plantas úteis do Brasil. Rio de Janeiro: MA/EBDF, 1969. v.4, p.547-550.

DANLEY, M.M.; VETTER, R.L. Changes in carbohydrate and nitrogen fractions and digestibility of forages: maturity and ensiling. Journal of Animal Science, v.37, n.4, p.994-999, 1973.

GOURLEY, L.M.; LUSK, J.W. Genetic parameters related to sorghum silage quality. Journal Dairy Science, v.61, n.12, p.1821-1827, 1978.

ÍTAVO, L.C.V.; SANTOS, G.T. dos.; JOBIM, C.C. et al. Efeito de aditivos nos parâmetros fermentativos da silagem de bagaço de laranja. In: REUNIÃO ANUAL DA SOCIEDADE BRASILEIRA DE ZOOTECNIA, 35., 1998, Viçosa, MG. Anais... Viçosa, MG: Sociedade Brasileira de Zootecnia, 1998. p.385-387.

JOHNSON, L.J.; McCLURE, K.E.; DEHORITY, B.A. Corn plant maturity. Journal of Animal Science, v.25, p.617-623, 1966.

LAVEZZO, W. Ensilagem do capim-elefante. In: SIMPÓSIO SOBRE MANEJO DE PASTAGEM, 10., 1992, Piracicaba. Anais... Piracicaba: Fundação de Estudos Agrários Luiz de Queiroz, 1992. p.169-275.

McDONALD, P.; HENDERSON, A.R.; HERON, S.J.E. The biochemistry of silage. New York: Chalcombe Publications, 1991. 339p.

MEESKE, R.; ASHBELL, G. et al. Ensiling forage sorghum at two stages of maturity with the addition of lactic acid bacterial inoculants. Animal Feed Science and Technology, v.43, n.2, p.165-175, 1993.

MUCK, R.E. Factores influencing silage quality and their implications for management. Journal of Dairy Science, v.71, n.11, p.2992-3002, 1988.

MUCK, R.E. Dry matter level on alfafa silage quality. II. Fermentation products and starch hydrolysis. Transaction of ASAE, v.33, n.2, p.373-381, 1990.

OLIVEIRA, J.S. Forragens para o gado leiteiro. São Paulo: Tortuga/Embrapa Gado de Leite, 1997. p.61-65.

OLIVEIRA, C.L.M.; GONÇALVES, L.C.; RODRIGUES, J.A.S. et al. Classificação de silagens de híbridos de Sorghum bicolor X Sorghum sudanense. In: REUNIÃO ANUAL DA SOCIEDADE BRASILEIRA DE ZOOTECNIA, 35., 1998,
Botucatu. Anais ... Botucatu: Sociedade Brasileira de Zootecnia, 1998. p.369-340.

PLAYNE, M.J.; McDONALD, P. The buffering constituints of herbage and of silage. Journal of the Science of Food and Agriculture, v.17, p.264-268, 1966.

PRESTON, T.R. Better utilization of crop residues and byproducts in animal feeding: research guidelines. 2 . A pratical manual for research workers. Rome: FAO, 1986. 154p.

SILVA, D.J. Análise de alimentos: métodos químicos e biológicos. 2.ed. Viçosa, MG: Universidade Federal de Viçosa, 1981. 165p.

SILVA, M.M.C; GUIM A.; PIMENTA FILHO, E.C. et al. Avaliação do padrão de fermentação de silagens elaboradas com espécies forrageiras do estrato herbáceo da caatinga nordestina. Revista Brasileira de Zootecnia, v.33, n.1, p.87-96, 2004.

SILVEIRA, A.C. Técnicas para produção de silagem. In: SIMPÓSIO SOBRE MANEJO DE PASTAGENS, 2., 1975, Piracicaba. Anais... Piracicaba: Escola Superior de Agricultura Luiz de Queiroz, 1975. p.187-217.

SILVEIRA, A.C. Produção e utilização de silagens. In: SEMANA DE ZOOTECNIA, 2., 1988, Campinas. Anais... Campinas: Fundação Cargill. 1988. p.119-134.

TAYAROL MARTIN, L.C. Bovinos: volumosos suplementares. São Paulo: Nobel, 1997. p.82-138.

TOSI, H. Conservação de forragem como conseqüência do manejo. In: SIMPÓSIO SOBRE MANEJO DE PASTAGENS. 1973, Piracicaba. Anais... Piracicaba: Fundação de Estudos Agrários Luiz de Queiroz, 1973. p.117-140.

TOSI, P.; MATTOS, W.R.S.; TOSI, H. et al. Avaliação química e microbiológica da silagem do capim-elefante cv taiwan A148, sob diferentes técnicas de redução de umidade. In: REUNIÃO ANUAL DA SOCIEDADE BRASILEIRA DE ZOOTECNIA, 34., 1997, Juiz de Fora. Anais ... Juiz de Fora: Sociedade Brasileira Zootecnia, 1997. p.206-208.

UMAÑA, R.; STAPLES, C.R.; BATES, D.B. et al. Effects of a microbial inoculant and(or) sugarcane molasses on the fermentation, aerobic stability and digestibility of bermudagrass ensiled two moisture contents. Journal of Animal Science, v.69, n.11, p.4588-4601, 1991.

UNIVERSIDADE FEDERAL DE VIÇOSA - UFV. SAEGSistema de análises estatísticas e genéticas. Versão 7.1. Viçosa, MG: 1997. 150p. (Manual do usuário).

VIEIRA, E.L.; SILVA, A.M.A.; COSTA, R.G. et al. Valor nutritivo do feno de espécies lenhosas da caatinga. In: REUNIÃO ANUAL DA SOCIEDADE BRASILEIRA DE ZOOTECNIA, 35., 1998, Botucatu. Anais... Botucatu: Sociedade Brasileira de Zootecnia, 1998. p.227-229.

VILELA, D. Aditivos na ensilagem. Coronel Pacheco: Embrapa Gado de Leite, 1984. (Circular Técnica, 21)

ZAGO, C.P. Cultura de sorgo para produção de silagem de alto valor nutritivo. In: SIMPÓSIO SOBRE NUTRIÇÃO DE BOVINOS, 4., 1991, Piracicaba. Anais... Piracicaba: Fundação de Estudos Agrários Luiz de Queiroz, 1991. p.169-217.
Recebido em: $17 / 04 / 03$ Aceito em: 26/07/04 